\title{
PENINGKATAN KEMAMPUAN MELAKUKAN LANGKAH-LANGKAH STOCK OPNAME MENGGUNAKAN METODE DEMONSTRASI
}

\author{
Aris Purwantinah \\ SMK Negeri 1 Bantul \\ arispurwantinah@gmail.com
}

\begin{abstract}
Abstrak: Penelitian ini termasuk penelitian tindakan kelas yang bertujuan untuk meningkatkan kemampuan melakukan langkah-langkah stock opname kelas XII Bisnis Daring dan Pemasaran (BDP) 3 SMK N I Bantul tahun ajaran 2019/2020. Penelitian ini menggunakan model Kemmis dan Taggart. Subyek penelitian ini adalah peserta didik kelas XII Bisnis Daring dan Pemasaran 3 dan objek penelitian ini adalah kemampuan melakukan langkah-langkah stock opname dengan menggunakan metode demonstrasi. Pengumpulan data dalam penelitian ini adalah dengan menggunakan tes, observasi, catatan lapangan, wawancara, dokumentasi, dan angket. Teknik analisa data menggunakan teknik deskriptif kualitatif dan kuantitatif. Validitas data menggunakan validitas demokratis, validitas proses, dan validitas dialogis. Hasil penelitian menunjukkan metode demonstrasi mampu meningkatkan kemampuan peserta didik dalam melakukan langkah-langkah stock opname melalui 2 siklus. Pada siklus I, peserta didik telah meningkat kemampuannya dibuktikan dengan saat sebelum tindakan nilai rata-rata hasil pre test 44,69 dan setelah dilakukan tindakan hasil tes tertulis meningkat nilai rata-rata kelasnya menjadi 80,16, sebanyak 19 anak telah mencapai KKM dan 13 anak belum mencapai KKM, sedangkan berdasarkan hasil nilai praktik sebanyak 16 anak dinyatakan mampu dan 16 anak belum mampu. Pada siklus II, hasil tes tertulis menunjukkan nilai rata-rata kelas 86,09, sebanyak $28(87,50 \%)$ anak telah KKM dan $4(12,50 \%)$ anak belum KKM, sedang pada nilai praktik sebanyak $32(100 \%)$ anak telah mampu.
\end{abstract}

Kata kunci: langkah-langkah stock opname, demonstrasi

\section{THE IMPROVEMENT OF THE ABILITY TO PERFORM STEPS OF STOCK OPNAME USING DEMONSTRATION METHOD}

Abstract: This research is an action research which aims to improve students' ability to perform steps of stock opname using demonstration method for students of class XII BDP3 of SMK N 1 Bantul batch 2019/2020.This research using Kemmis and Taggart model which used cycles. The subjects of the research were students of class XII BDP 3 and the object of the research was ability to perform steps of stock opname using demonstration method. The data collection was done through tests, observations, field notes, interviews, documentations, and questionnaire. The data analysis techniques employed in this research were qualitative descriptive and quantitative. The data validities used were democratic validity, process validity, and dialogic validity. The results of the research show that demonstration method could improve the students' ability in steps of stock opname through two cycles. In cycle 1, students had increased the ability which shown the average score of the pre-test before the treatment was 44,69 and after the students were given treatment in cycle I, the average score was 80,16 with 19 students were reach the Minimum Learning Mastery Standard (KKM) and only 13 students were not reach KKM, meanwhile, based on the results of the practice, 16 students were capable of performing steps of stock opname and 16 students were not capable yet. In cycle 2, the results of the written tests were shown the average score 86,09 with 28 students or 87,50\% passed the Minimum Learning Mastery Standard (KKM) and 4 students or $12,50 \%$ had not pass KKM. Meanwhile, the results of the practice show 32 students or 100\% were capable of performing stock opname's steps.

Keywords: steps of stock opname, demonstration.

\section{PENDAHULUAN}

Pada era revolusi industri 4.0, pemerintah melalui kementerian pendidikan menekankan pada revitalisasi SMK agar lulusan SMK menjadi lulusan yang handal serta menguasai bidang yang diampunya. Untuk mewujudkan 
tujuan tersebut hendaknya guru selalu berupaya untuk selalu mengembangkan profesionalisme peserta didik agar siap memasuki lapangan kerja yang sesuai dengan bidang keahliannya.

Uji kompetensi yang menjadi ajang unjuk kerja kompetensi peserta didik oleh pemerintah sudah diarahkan pada SKKNI sehingga penilaian tingkat kompetensinya menggunakan standar nasional yaitu BNSP. Adapun standar kompetensi yang berlaku untuk lulusan SMK dengan masa belajar 3 tahun adalah skema level II. Oleh sebab itu guru dituntut harus bisa membuat peserta didik betul-betul memiliki kemampuan sesuai standar yang ditetapkan SKKNI. Kompetensi Melakukan Stock Opname merupakan salah satu kompetensi yang ditetapkan dalam skema level II dengan kode KOP.RK02.011.01. Karena sudah ditetapkan dalam skema level II yang menjadi acuan ujian kompetensi maka guru harus menjamin peserta didik betul-betul memiliki kemampuan dalam melakukan stock opname.

Namun kenyataannya peserta didik masih belum memiliki kompetensi yang diharapkan. Hal ini terbukti saat guru melakukan observasi awal menanyakan contoh bentuk kartu persediaan, banyak yang tidak tahu Mereka menjawab bahwa guru belum memberikan materi tentang kartu persediaan padahal kartu persediaan ini menjadi bagian materi Administrasi Transaksi pada kelas XI. Hal ini bisa disebabkan karena peserta didik kurang memperhatikan guru. Kurangnya perhatian peserta didik pada guru bisa disebabkan karena proses pembelajarannya berpusat pada guru (teacher centered) atau proses pembelajarannya belum sepenuhnya melibatkan keaktifan peserta didik sehingga materi yang disampaikan guru kurang dikuasai dengan baik. Dengan demikian dapat disimpulkan bahwa peserta didik kelas XII Bisnis Daring dan Pemasaran (BDP) 3 SMK Negeri I Bantul masih rendah tingkat pemahamannya yang disebabkan pemahaman pada teori saja kurang, apalagi penguasaan pada keterampilannya yang mengacu pada SKKNI. Untuk bisa membuat peserta didik memiliki kemampuan tinggi, berkualitas, dan sanggup memenuhi kebutuhan dunia kerja maka dalam melakukan kegiatan proses pembelajaran guru harus memperhatikan attitude, proses, produk.

Pembelajaran melakukan stock opname diantaranya memuat kompetensi langkahlangkah melakukan stock opname yang benar, dokumen-dokumen yang digunakan saat melakukan stock opname, cara mengisi dokumen saat melakukan stock opname, dan membuat laporan hasil stock opname. Kompetensi ini bisa dikuasai peserta didik jika pembelajarannya dipraktikkan, artinya peserta didik betul-betul melakukan praktik kegiatan stock opname secara langsung. Dengan belajar mempraktikkan langkah-langkah melakukan stock opname, membuat dokumen dan mengisi dokumen stock opname, serta membuat laporan stock opname peserta didik akan mengetahui secara konkrit langkah-langkah stock opname sekaligus dapat mengaplikasikan langkahlangkah stock opname seperti sesuai kenyataannya. Peserta didik menjadi tidak bingung terhadap teori yang didapatkan karena mampu membuktikan dengan melakukan langkah-langkah yang dijalankan secara praktik langsung. Dengan dipraktikkan maka mampu tidaknya peserta didik dalam melakukan stock opname mudah diukur. Kompetensi melakukan stock opname adalah suatu kompetensi atau keterampilan yang harus dipraktikkan maka guru harus bisa memfasilitasi dengan menentukan metode yang tepat dan membuat lembar kerja yang menuntut peserta didik harus mampu melakukan praktik langkah-langkah stock opname. Kegunaan pembelajaran secara praktik langsung ini diperkuat oleh pendapat Wallace dalam I Gusti Ayu Dariyati (2015:3). Wallace menjelaskan bahwa efektifnya pembelajaran praktik tergantung pada bagaimana peserta didik melakukan refleksi dengan mengkaitkan antara pengetahuan dan pengalaman serta praktik, sehingga dapat memperbaiki pembelajaran lebih lanjut. Kemampuan melakukan refleksi dari praktik yang didasarkan pada pengalaman dan pengetahuan menentukan pencapaian kompetensi profesional.

Berdasarkan pada materi dan keterampilan yang harus dikuasai peserta didik dalam melakukan langkah-langkah stock opname maka metode pembelajaran praktik yang sesuai digunakan adalah praktik demonstrasi. Menurut Syah (2000: 22) metode demonstrasi adalah adalah metode mengajar dengan cara memperagakan barang, kejadian, aturan dan urutan melakukan sesuatu kegiatan, baik secara langsung maupun melalui penggunaan media pembelajaran yang relevan dengan pokok bahasan atau materi yang sedang disajikan. Untuk meningkatkan kemampuan melakukan langkah-langkah stock opname, guru harus 
mengajak peserta didik memperagakan langkah-langkah melakukan kegiatan stock opname, membuat dan mengisi dokumen dengan baik dan benar, menghitung stok barang dan melaporkan hasil perhitungan stock opname. Melalui metode demonstrasi ini peserta didik dapat berlatih dan praktik melakukan langkah-langkah melakukan stock opname secara urut sesuai prosedur dan bisa mempraktikkan penggunaan dokumen yang sesuai saat melakukan satu langkah kegiatan stock opname. Peserta didik juga bisa mengisi dokumen sesuai dengan dokumen sumber yang dijadikan sebagai $\mathrm{n}$ acuan pengisian. Demikian juga saat membuat laporan stock opname, peserta didik menjadi tahu bagaimana cara membuat dan mengisi laporan stock opname serta dokumen apa saja yang digunakan untuk membuat laporan stock opname. Penerapan metode demonstrasi bisa mendorong peserta didik untuk lebih serius dalam mengerjakan tugas dan latihan. Oleh karena itu penggunaan metode demonstrasi diharapkan mampu meningkatkan kemampuan melakukan stock opname pada peserta didik kelas XII BDP 3 SMK Negeri I Bantul tahun ajaran 2019/2020.

Berdasarkan latar belakang masalah di atas maka rumusan masalah yang akan dipecahkan pada penelitian ini adalah "Bagaimana penerapan metode demonstrasi dapat meningkatkan kemampuan dalam melakukan langkah-langkah stock opname pada peserta didik kelas XII BDP 3 SMK Negeri I Bantul tahun ajaran 2019/2020?"

Penggunaan metode demonstrasi mampu meningkatkan kemampuan melakukan langkah-langkah stock opname karena metode demonstrasi memiliki tujuan menurut Rochman ( 2007: 98) adalah untuk memperjelas pengertian konsep dan memperlihatkan cara melakukan sesuatu atau proses terjadinya sesuatu seperti: (1) mengajar siswa tentang suatu tindakan, proses atau prosedur; (2) keterampilan-keterampilan fisik dan motorik; (3) mengembangkan kemampuan pengamatan pendengaran dan penglihatan para siswa secara bersama - sama; (4) mengkonkritkan informasi yang disajikan kepada siswa.

Oleh sebab itu penelitian ini akan menerapkan metode demonstrasi untuk meningkatkan kemampuan peserta didik dalam melakukan langkah-langkah stock opname.

\section{METODE PENELITIAN \\ Jenis Penelitian}

Jenis penelitian ini adalah penelitian deskriptif kualitatif dengan berorientasi pada peningkatan mutu pembelajaran dengan menggunakan rancangan Penelitian Tindakan Kelas (PTK). Prosedur pelaksanaan PTK diawali dengan mengidentifikasi permasalahan yang muncul di sekolah.

\section{Waktu dan Tempat}

Penelitian ini dilaksanakan pada semester ganjil tahun ajaran 2019/2020 yaitu mulai bulan Oktober sampai dengan bulan Nopember 2019. Penelitian ini dilaksanakan di SMK Negeri I Bantul pada kelas XII Bisnis Daring dan Pemasaran 3 dengan jumlah siswa sebanyak 32 anak.

\section{Subjek Penelitian}

Subyek penelitian yang dipilih dalam penelitian ini adalah kelas XII BDP 3 tahun ajaran 2019/2020. Penetapan kelas XII BDP 3 sebagai subyek dalam penelitian ini disebabkan karena peserta didik belum memiliki kompetensi yang tinggi, pasif, sehingga guru pengampu harus mengaplikasikan metode pembelajaran yang sesuai agar peserta didik dapat berkembang secara maksimal.

\section{Prosedur Penelitian}

Adapun prosedur penelitian ini mengacu pada PTK menggunakan desain penelitian tindakan Kemmis dan Taggart. Pada tiap siklus terdiri dari perencanaan, pelaksanaan tindakan, observasi dan refleksi. Pada tahap perencanaan yang perlu dilakukan adalah menyiapkan RPP, materi, instrumen penelitian, rancangan langkah-langkah tindakan kelas, LKS, alat ukur yang akan digunakan, dan menyiapkan bahanbahan untuk kepentingan praktik demonstrasi melakukan langkah-langkah stock opname. Tahap pelaksanaan yang dilakukan adalah melakukan proses pembelajaran sesuai skenario yang direncanakan dengan diawasi kolaborator. Pada tahap observasi dan evaluasi adalah selama pembelajaran kolaborator mengamati dan mencatat peran guru sebagai fasilitator dan peserta didik sebagai subyek penelitian serta melakukan evaluasi hasil belajar baik praktik maupun tertulis hasil dari tindakan kelas. Sedangkan pada tahap refleksi mengumpulkan sejumlah data hasil refleksi dan respon peserta didik selama mengikuti proses pembelajaran, hasil tes, hasil observasi 
kolaborator yang digunakan untuk memperoleh informasi hasil siklus I dan data temuan atau hambatan pada siklus I untuk diperbaiki pada siklus II.

\section{Data, Instrumen, dan Teknik Pengumpulan Data}

Sumber data penelitian tindakan ini meliputi peserta didik, guru, dokumen hasil pembelajaran, dan proses pembelajaran. Adapun teknik pengumpulan datanya dilakukan dengan cara sebagai berikut:

a. Pembuatan laporan tertulis berupa tugastugas kelompok. Laporan tugas tertulis digunakan untuk mengetahui tingkat kemampuan siswa dalam memahami materi maupun kemampuan menerapkan langkahlangkah stock opname.

b. Wawancara terhadap peserta didik, untuk mengetahui pendapat peserta didik tentang tingkat pemahaman materi, jalannya proses pembelajaran.

c. Observasi, untuk mengetahui sikap peserta didik maupun pelaksanaan kegiatan demonstrasi selama pelaksanaan tindakan kelas.

d. Angket, yaitu pertanyaan tertulis yang memerlukan jawaban tertulis yang berkaitan dengan masalah yang diteliti , bisa berupa angket terbuka maupun tertutup dengan jawaban tidak setuju, kurang setuju,setuju, sangat setuju.

e. Hasil tes, hasil tes untuk mengukur prestasi peserta didik sebelum dan sesudah dilakukan tindakan kelas.

Instrumen dalam penelitian ini adalah sebagai berikut:

a. Pedoman observasi /lembar observasi digunakan untuk mengungkapkan aktivitas guru ketika mengajar di kelas maupun aktifitas peserta didik selama mengikuti proses belajar, fasilitas yang digunakan oleh guru dalam pelaksanaan pengajaran, serta meningkatkan kemampuan melakukan langkah-langkah stock opname.

b. Catatan lapangan yaitu mencatat persoalanpersoalan yang menarik. Catatan ini mencakup kesan dan penafsiran terhadap peristiwa yang terjadi di kelas ketika tindakan dilaksanakan.

c. Portofolio yaitu kumpulan tugas siswa yang teratur dan bulat untuk menghasilkan suatu kompetensi tertentu.

d. Angket, digunakan memperoleh jawaban respon peserta didik tentang hasil pembelajaran. e. Soal tes, tes yang digunakan adalah tes pilihan ganda untuk mengetahui tingkat kemampuan peserta didik.

f. Pedoman observasi praktik demonstrasi yang digunakan untuk mengamati dan menilai tingkat kemampuan peserta didik dalam melakukan langkah-langkah stock opname.

\section{Teknik Analisis Data}

Penelitian tindakan kelas ini merupakan penelitian kualitatif dengan teknik analisa data menggunakan data kuantitatif dan kualitatif. Analisis kuantitatif untuk data kuantitatif sedangkan analisis kualitatif untuk data kualitatif.

Data kuantitatif diperoleh dari hasil penilaian tugas serta hasil tes maupun hasil pengamatan kemampuan praktik demonstrasi melakukan langkah-langkah stock opname. Sedangkan data kualitatif diperoleh dari hasil observasi atau pengamatan sikap dan angket respon peserta didik atau dari hasil wawancara guru dengan murid.

Indikator keberhasilan tindakan kelas ini meliputi:

a. Keberhasilan proses. Keberhasilan proses dapat dilihat dari hasil pengamatan maupun angket respon, penelitian tindakan ini dikatakan telah berhasil jika peserta didik semakin berperan aktif, tertarik mengikuti pelajaran, dan memiliki respon yang positif pada penerapan metode demonstrasi.

b. Keberhasilan produk. Keberhasilan produk dapat dilihat dari hasil laporan portofolio dan hasil nilai tes baik tes tertulis maupun praktik, penelitian ini telah berhasil apabila sebanyak $85 \%$ jumlah peserta didik suatu kelas telah memenuhi KKM yaitu dengan nilai 80 .

\section{HASIL DAN PEMBAHASAN Hasil}

Penelitian tindakan kelas ini dilakukan dengan 2 siklus. Siklus I dilakukan selama 7 kali pertemuan sedang pada siklus II dilakukan selama 4 kali pertemuan. Hasil yang diperoleh selama 2 siklus ini menunjukkan hasil bahwa metode demonstrasi dapat meningkatkan kemampuan peserta didik kelas 12 Bisnis Daring dan Pemasaran 3 tahun ajaran 2019/2020 dalam melakukan langkah-langkah stock opname.

Pada siklus I tindakan yang dilakukan guru bersama kolaborator untuk meningkatkan 
kemampuan pada peserta didik dilakukan dengan langkah-langkah sebagai berikut: (1) guru memberikan fasilitas kepada peserta didik agar peserta didik memahami pengertian stock opname; (2) guru memberikan fasilitas kepada peserta didik menjelaskan tujuan dan manfaat kegiatan stock opname; (3) guru memfasilitasi peserta didik mampu menganalisis dokumendokumen yang digunakan dalam melakukan kegiatan stock opname; (4) guru memfasilitasi peserta didik untuk menerapkan langkahlangkah melakukan stock opname dengan cara guru memberikan latihan berupa membuat dan mengisi dokumen stock opname, membuat urutan langkah-langkah melakukan stock opname, membuat skenario langkah-langkah melakukan stock opname, dan memberikan contoh demonstrasi langkah-langkah stock opname, (5) guru meminta peserta didik menyiapkan bahan/alat kebutuhan untuk melakukan demonstrasi langkah-langkah stock opname; (6) guru memfasilitasi peserta didik latihan mendemonstrasikan langkah-langkah melakukan stock opname; (7) guru meminta peserta didik dalam satu kelompok melakukan demonstrasi langkah-langkah -langkah stock opname. Langkah-langkah di atas dilakukan guru selama 7 kali pertemuan @ 3 jam pelajaran. Berdasarkan pengamatan kolaborator selama melakukan proses pembelajaran, peserta didik meningkat sikap positifnya ditandai dengan meningkatnya motivasi belajar, aktif mendengarkan pelajaran dan berdiskusi, memiliki tanggung jawab menyelesaikan tugas, antusias mengikuti kegiatan pada setiap pertemuan, hingga pada akhir pertemuan jumlah peserta didik yang memiliki sikap-sikap positif seperti di atas mencapai $81,25 \%$. Hal ini menunjukkan telah terjadi keberhasilan proses. Sedangkan keberhasilan produk pada siklus I ditandai dengan meningkatnya jumlah peserta didik yang sudah kompeten dilihat dari nilai tes akhir (post test) dan nilai praktik. Dilihat dari hasil tes, hasil tes sebelum dilakukan tindakan menunjukkan bahwa peserta didik belum ada yang mencapai KKM dengan nilai rata-rata kelas 44,69 dan setelah dilakukan tindakan pada siklus I hasil tes akhir menunjukkan sebanyak $19(59,38 \%)$ anak sudah KKM dan 13 $(40,62 \%)$ anak belum KKM dengan nilai ratarata kelas 80,16 . Sedangkan jika dilihat dari nilai praktik menunjukkan sebanyak 16 anak telah dinyatakan kompeten dalam melakukan langkah-langkah stock opname dan 16 anak lainnya belum kompeten. Kriteria peserta didik dinyatakan KKM dan kompeten pada penelitian ini jika nilai minimal 80. Ada beberapa hal yang menyebabkan peserta didik belum KKM maupun kompeten pada siklus I antara lain peserta didik masih belum memahami tentang dokumen baik itu dari segi penggunaan maupun cara mengisinya. Peserta didik juga belum memahami tentang langkahlangkah stock opname baik dari segi urutannya, siapa yang harus mengerjakan mulai dari persiapan, pelaksanaan maupun pelaporan. Pada saat persiapan stock opname banyak peserta didik yang masih mengalami kesulitan dalam melakukan up date data barang, demikian juga pada saat pelaporan.

Peserta didik mengalami kesulitan dalam mengisi laporan stock opname dan berita acara stock opname. Secara lebih lengkap hasil rekap peningkatan kemampuan peserta didik dalam melakukan langkah-langkah stock opname pada siklus I ditunjukkan pada tabel berikut.

Tabel 1. Rekap Hasil Praktik Demonstrasi Siklus I

\begin{tabular}{ccccc}
\hline \multicolumn{5}{c}{ MAMPU } \\
\hline Koordinator & Petugas Gudang & Tim Tag & Tim Stock Opname & Jumlah \\
5 Anak & 4 Anak & 3 Anak & 4 Anak & 16 Anak \\
Kelp 1,2,3,4,7 & Kelp.4,6,7,8 & Kelp. 6,7,8 & Kelp. 2,3,4,5 & \\
\hline \multicolumn{5}{c}{ BELUM MAMPU } \\
\hline 3 Anak & 4 Anak & 5 Anak & 4 Anak & 16 Anak \\
Kelp.5,6,8 & Kelp.1,2,3,5 & Kelp.1,2,3,4,5 & Kelp.1,6,7,8 & Kelp. \\
\hline
\end{tabular}

Berdasarkan data di atas dapat disimpulkan bahwa pada siklus I metode demonstrasi telah berhasil meningkatkan kemampuan peserta didik namun belum mencapai kriteria yang ditetapkan. Oleh sebab itu guru harus memperbaiki hambatan dalam rangka mengatasi kesulitan yang dialami peserta didik dengan melakukan tindakan perbaikan pada siklus II. 
Pada siklus II guru bersama kolaborator merencanakan strategi untuk mengatasi hambatan pada siklus I. Ada beberapa hal yang harus dilakukan guru untuk mengambil tindakan pada siklus II guna memperbaiki siklus I yaitu;

- Guru perlu memperjelas kembali materi mengenai dokumen, langkah-langkah stock opname, dan laporan stock opname.

- Guru harus semakin mengaktifkan peserta didik dalam suasana belajar yang kooperatif learning apalagi menghadapi peserta didik yang masih belum berani dan kurang percaya diri, kurang aktif, malu berpendapat.

- Guru perlu membimbing dalam melakukan demonstrasi langkah-langkah stock opname dengan mengoptimalkan keaktifan peserta didik.

Rencana tindakan kelas di atas menurut pendapat guru dan kolaborator dapat digunakan untuk mengatasi hambatan yang terjadi pada siklus I. Untuk merealisasikan tindakan kelas di atas guru bersama kolaborator akan menggunakan model pembelajaran cooperative learning tipe Jigsaw. Dengan model pembelajaran kooperatif tipe Jigsaw akan mendorong peserta didik menjadi lebih aktif dan saling membantu dalam menguasai materi. Hal ini sesuai dengan pendapat Suyanto (2013: 169) yang menyatakan penerapan model pembelajaran kooperatif tipe Jigsaw dalam proses belajar dapat menumbuhkan tanggung jawab siswa sehingga mereka terlibat langsung secara aktif dalam memahami suatu persoalan dan menyelesaikanya secara berkelompok. Mereka pun bisa bertindak berdiskusi maupun berlatih demonstrasi langkah-langkah stock opname dengan teman sebaya dan guru akan bertindak sebagai motivator dan fasilitator.

Dalam menerapkan model pembelajaran tipe Jigsaw guru bersama kolaborator akan mengambil langkah-langkah sebagai berikut:

- Guru kembali akan menerangkan atau menjelaskan kembali mengenai dokumen stock opname, langkah-langkah melakukan stock opname dan laporan stock opname secara teori dengan mengambil contohcontoh seperti yang dipraktikkan dalam demonstrasi langkah-langkah stock opname.

- Guru menunjuk peserta didik yang sudah jelas akan materi yang dipelajari dan sudah mampu melakukan praktik demonstrasi pada siklus I untuk menjadi kelompok (tim) ahli yang akan dibimbing guru untuk menjadi tutor sebaya dan bisa memotivasi teman-temannya.

Berdasarkan strategi yang akan diambil guru dan kolaborator seperti tersebut di atas, guru bersama kolaborator selanjutnya menyusun perencanaan dan pelaksanaan tindakan kelas. Perencanaan meliputi: (1) Mempersiapkan RPP perbaikan dengan titik pusat perhatian proses pembelajarannya untuk memperbaiki kelemahan proses pembelajaran yang dilakukan pada siklus I; (2) Mempersiapkan lembar kerja untuk memperjelas materi; (3) Mempersiapkan dokumen, alat, bahan untuk praktik demonstrasi; (4) Menentukan tim ahli.

Sedangkan implementasi tindakan dilakukan dengan langkah-langkah sebagai berikut:

(1) Guru memperjelas kembali materi dokumen stock opname, langkah-langkah stock opname, dan laporan stock opname yang dituangkan dalam RPP perbaikan.

(2) Untuk memperjelas materi guru memberikan latihan tambahan tentang dokumen stock opname, langkah-langkah stock opname, dan laporan stock opname yang dituangkan dalam RPP perbaikan.

(3) Setelah semua peserta didik jelas akan materi yang diberikan, guru menunjuk tim ahli yang sudah mampu dalam hal pengetahuan dan keterampilan untuk menjadi tutor sebaya diantara temanteman dalam kelompoknya. Tim ahli ini akan menjadi tutor sebaya dalam melakukan latihan demonstrasi langkahlangkah stock opname. Tim ahli yang ditunjuk meliputi koordinator, petugas gudang, tim tag, dan petugas stock opname.

(4) Tim Ahli sebagai tutor sebaya mempresentasikan atau memberi contoh cara demonstrasi langkah-langkah stock opname dengan pengawasan dan pembimbingan guru.

(5) Tim ahli menuju kelompok yang menjadi bimbingannya bertugas memberikan tutor sebaya dalam latihan mendemonstrasikan kegiatan stock opname. Guru mengawasi dan membimbing kegiatan latihan demonstrasi.

(6) Tim ahli kembali ke kelompok asal bila kelompok yang menjadi bimbingannya sudah mampu melakukan langkahlangkah stock opname secara mandiri. 
(7) Setelah memperoleh latihan dari tim ahli, setiap kelompok melakukan latihan demonstrasi secara mandiri.

(8) Pada akhir siklus II guru menilai kegiatan demonstrasi yang dilakukan setiap kelompok secara mandiri

Setelah dilakukan tindakan pada siklus II dengan mengacu pada langkah-langkah tersebut di atas, hasil observasi kolaborator dan guru menunjukkan bahwa telah terjadi peningkatan kemampuan melakukan langkahlangkah stock opname pada peserta didik. Hal ini dibuktikan dengan meningkatnya peserta didik yang memiliki sifat positif yang mencapai $100 \%$. Semua peserta didik memiliki motivasi, aktif mendengarkan, aktif berdiskusi, bertanggung jawab terhadap tugas, memiliki semangat dan rasa senang. Pembelajaran kooperatif dengan bantuan tim ahli dan penggunaan metode demonstrasi diterapkan pada semua kelompok mampu menggerakkan aktivitas pembelajaran menjadi lebih menarik dan memotivasi peserta didik untuk menyelesaikan seluruh kegiatannya. Ini menunjukkan adanya keberhasilan proses yang dicapai pada siklus II dimana keberhasilan proses telah mencapai kriteria yang ditetapkan dalam penelitian ini. Berdasarkan keberhasilan produk menunjukkan bahwa hasil tes tertulis sebanyak $28(87,50 \%)$ anak telah mencapai KKM dan $4(12,50 \%)$ anak belum dinyatakan
KKM, sedangkan dilihat dari hasil praktik melakukan langkah-langkah stock opname sebanyak 32 (100\%) anak telah kompeten. Dengan demikian pada siklus II peserta didik telah meningkat kemampuan melakukan langkah-langkah stock opname dibandingkan pada siklus I. Keberhasilan produk ini telah sesuai dengan kriteria yang ditetapkan pada penelitian ini karena lebih dari $85 \%$ anak mampu melakukan langkah-langkah stock opname dengan nilai KKM 80. Perbandingan hasil capaian keberhasilan tindakan kelas pada siklus I dan siklus II dapat dilihat pada tabel di bawah ini.

Berdasarkan table nilai pengetahuan bagi peserta didik yang belum tuntas pada siklus II nilainya lebih tinggi dibandingkan pada siklus I dimana nilai terendah pada siklus I adalah 60 sedangkan pada siklus II 70 dan 75 . Nilai ratarata tes tertulis pada siklus I adalah 80,16 dan pada siklus II nilai rata-rata naik menjadi 86,09 dari 32 anak. Sedangkan jika dilihat dari nilai keterampilan pada siklus I 50\% anak baru dinyatakan kompeten dan 50\% lainnya belum kompeten. Dari 32 anak nilai keterampilan yang banyak muncul ada di rentang nilai 80-85. Berbeda pada siklus II dimana $100 \%$ anak sudah dinyatakan kompeten dan nilai keterampilan yang banyak muncul adalah pada rentang 96-100.

Tabel 2. Perbandingan Nilai Pengetahuan dan Keterampilan Siklus I dan Siklus II

\begin{tabular}{|c|c|c|c|c|c|c|c|c|c|c|}
\hline \multicolumn{6}{|c|}{ Nilai Pengetahuan } & \multicolumn{5}{|c|}{ Nilai Keterampilan } \\
\hline \multirow{2}{*}{ No } & \multirow{2}{*}{ Nilai } & \multicolumn{2}{|c|}{ Siklus I } & \multicolumn{2}{|c|}{ Siklus II } & \multirow{2}{*}{$\begin{array}{c}\text { Rentang } \\
\text { Nilai }\end{array}$} & \multicolumn{2}{|c|}{ Siklus I } & \multicolumn{2}{|c|}{ Siklus II } \\
\hline & & $\mathrm{Jml}$ & $\mathrm{T} / \mathrm{BT}$ & $\mathrm{Jml}$ & T/BT & & $\mathrm{Jml}$ & $\mathrm{M} / \mathrm{BM}$ & $\mathrm{Jml}$ & $\mathrm{M} / \mathrm{BM}$ \\
\hline 1 & 60 & 1 & BT & 0 & & $55-60$ & 0 & & & \\
\hline 2 & 65 & 0 & & 0 & & $61-64$ & 0 & & & \\
\hline 3 & 70 & 5 & BT & 3 & BT & $65-70$ & 6 & $\mathrm{BM}$ & & \\
\hline 4 & 75 & 7 & BT & 1 & BT & $71-75$ & 6 & $\mathrm{BM}$ & & \\
\hline 5 & 80 & 8 & $\mathrm{~T}$ & 8 & $\mathrm{~T}$ & $76-79$ & 5 & $\mathrm{BM}$ & & \\
\hline 6 & 85 & 5 & $\mathrm{~T}$ & 5 & $\mathrm{~T}$ & $80-85$ & 8 & M & 2 & M \\
\hline 7 & 90 & 3 & $\mathrm{~T}$ & 8 & $\mathrm{~T}$ & $86-90$ & 7 & $\mathrm{M}$ & 7 & M \\
\hline 8 & 95 & 1 & $\mathrm{~T}$ & 3 & $\mathrm{~T}$ & $91-95$ & 0 & & 6 & M \\
\hline \multirow[t]{4}{*}{9} & 100 & 2 & $\mathrm{~T}$ & 4 & $\mathrm{~T}$ & $96-100$ & 1 & M & 17 & $\mathrm{M}$ \\
\hline & & 32 & T 19 & 32 & T 32 & & 32 & M 16 & 32 & M 32 \\
\hline & & anak & BT 13 & anak & BT 0 & & anak & BM 16 & anak & BM 0 \\
\hline & & $\begin{array}{l}\text { Nilai } \\
\text { rata- } \\
\text { rata }\end{array}$ & 80,16 & $\begin{array}{l}\text { Nilai } \\
\text { rata- } \\
\text { rata }\end{array}$ & 86,09 & & $\begin{array}{l}\text { Nilai } \\
\text { Modus }\end{array}$ & $80-85$ & $\begin{array}{l}\text { Nilai } \\
\text { Modus }\end{array}$ & $\begin{array}{l}96- \\
100\end{array}$ \\
\hline
\end{tabular}

\section{Pembahasan}

Berdasarkan data-data hasil keberhasilan proses dan keberhasilan produk berupa hasil tes tertulis dan hasil praktik demonstrasi langkah- langkah stock opname membuktikan bahwa metode demonstrasi mampu meningkatkan kemampuan melakukan stock opname. Mulai dari siklus I hasil yang dicapai sudah 
menunjukkan adanya peningkatan dimana dilihat dari hasil tes tertulis peserta didik yang sudah KKM sebanyak 19 anak dan 13 anak belum KKM, sedangkan jika dilihat dari nilai praktik demonstrasi sebanyak 16 anak yang sudah kompeten dan 16 anak lainnya belum kompeten. Walaupun pada siklus I belum menunjukkan hasil sesuai kriteria yang ditetapkan, namun penggunaan metode demonstrasi mampu memberikan pengalaman belajar yang bermakna bagi peserta didik. Oleh sebab itu guru melalui siklus II berusaha memperbaiki hambatan atau kesulitan yang terjadi pada siklus I dengan metode demonstrasi didukung dengan penggunaan metode Jigsaw sebagai model pembelajaran kolaboratif dan kooperatif yang tujuannya adalah untuk lebih meningkatkan motivasi dan keaktifan kelompok. Alasan penggunaan metode Jigsaw adalah supaya peserta didik lebih aktif dalam belajar kelompok dan mampu memecahkan persoalan yang dihadapi. Hal ini sesuai pendapat Rusman (2011:206) yang menyatakan pembelajaran kooperatif akan efektif digunakan apabila: (a) guru menekankan pentingnya usaha bersama di samping usaha secara individual, (b) guru menghendaki pemerataan perolehan hasil dalam belajar, (c) guru ingin menanamkan tutor sebaya atau belajar melalui teman sendiri, (d) guru menghendaki adanya pemerataan partisipasi aktif siswa, (e) guru menghendaki kemampuan siswa dalam memecahkan berbagai permasalahan. Setelah menerapkan metode demonstrasi didukung metode pembelajaran aktif tipe Jigsaw hasil yang dicapai pada siklus II adalah berdasarkan hasil tes tertulis 28 anak telah KKM dan 4 anak belum KKM, dan berdasarkan hasil praktik sebanyak 32 anak telah kompeten.

Hasil tersebut di atas membuktikan bahwa metode demonstrasi telah mampu memberikan kemudahan kepada peserta didik dalam meningkatkan kemampuan melakukan langkah-langkah stock opname. Tidak hanya sekedar kemampuan teori tetapi yang lebih penting adalah kemampuan keterampilannya mengingat keterampilan lebih banyak diterapkan peserta didik di dunia kerja. Dengan demikian metode demonstrasi bisa meningkatkan kemampuan peserta didik baik dari segi teori maupun praktik. Metode demonstrasi membantu peserta didik dalam mempelajari fakta, prinsip, konsep. Metode demonstrasi telah memberikan banyak pengalaman kepada peserta didik dalam meningkatkan kemampuannya melakukan langkah-langkah stock opname. Kenyataan ini didukung pendapat Anitah (2009:5.25) bahwa demonstrasi digunakan untuk: (a) mengonkretkan suatu konsep atau prosedur yang abstrak; (b) mengajarkan bagaimana berbuat atau menggunakan prosedur yang tepat; (c) meyakinkan bahwa alat atau prosedur bisa digunakan; (d) membangkitkan minat menggunakan alat atau prosedur.

Pendapat serupa juga dinyatakan Daradjat (2008:307) yang menyatakan metode demonstrasi membuat perhatian peserta didik lebih terpusatkan pada pelajaran yang sedang diberikan, kesalahan-kesalahan yang terjadi bila pelajaran diceramahkan dapat diatasi melalui pengamatan dan contoh konkrit, sehingga yang diterima peserta didik lebih mendalam dan tinggal lebih lama. Metode demonstrasi dapat mendorong peserta didik untuk berpartisipasi aktif, peserta didik lebih mudah memahami, dan proses pembelajaran lebih menarik. Oleh sebab itu berdasarkan hasil penelitian ini metode demonstrasi tepat digunakan untuk mempelajari langkah-langkah melakukan stock opname.

\section{SIMPULAN}

Berdasarkan hasil penelitian dan pembahasan, metode demonstrasi dapat meningkatkan kemampuan peserta didik kelas XII BDP 3 SMK N I Bantul tahun ajaran 2019/2020 dalam melakukan langkah-langkah stock opname terbukti pada hasil pembelajaran pada siklus I terjadi peningkatan sikap positif pada peserta didik dan keberhasilan produk dengan 19 anak mencapai KKM dan yang belum KKM 13 anak, sedangkan pada hasil praktik demonstrasi sebanyak 16 anak dinyatakan kompeten dan 16 anak belum kompeten. Adapun cara untuk meningkatkan kemampuan peserta didik menggunakan metode demonstrasi pada siklus I adalah peserta didik ditingkatkan pemahamannya tentang langkah-langkah stock opname dengan memberikan LKS, membuat skenario langkahlangkah stock opname, diberikan contoh praktik demonstrasi melakukan langkahlangkah stock opname, dan kemudian diminta mendemonstrasikan skenario yang dibuatnya. Dengan menggunakan langkah-langkah tersebut ternyata masih banyak peserta didik yang mengalami hambatan dalam mewujudkan kemampuannya sesuai yang ditetapkan dalam 
kriteria penelitian ini. Hambatan ini disebabkan karena peserta didik belum memahami tentang dokumen stock opname dan langkah-langkah stock opname mulai dari persiapan, pelaksanaan, maupun pelaporannya. Untuk itu guru mengatasi hambatan tersebut dengan melakukan tindakan pada siklus II.

Pada siklus II guru mengambil strategi dalam menerapkan metode demonstrasi yaitu dengan mengoptimalkan peran semua peserta didik untuk aktif melakukan pembelajaran secara kolaboratif dan kooperatif dengan menunjuk tim ahli untuk menjadi tutor sebaya di bawah pengawasan guru. Ternyata hasilnya sangat efektif karena suasana belajar menjadi lebih menyenangkan dan peserta didik dengan bantuan teman ahlinya tidak takut bertanya jika terdapat hal-hal yang belum jelas. Di samping itu penggunaan waktu belajar lebih efisien. Dengan menerapkan strategi tersebut maka pada siklus II peserta didik menjadi lebih mudah memahami dan berhasil sesuai dengan kriteria keberhasilan yang ditetapkan pada penelitian Tindakan kelas ini. Adapun langkahlangkah yang dilakukan guru pada siklus II ini adalah guru memperjelas materi dan memberi latihan tambahan dalam LKS, menunjuk tim ahli dari peserta didik yang sudah kompeten pada siklus I untuk dijadikan tutor sebaya, melatih tim ahli, memfasilitasi peserta didik dalam latihan demonstrasi yang dipandu tim ahli, praktik demonstrasi bila setiap kelompok sudah merasa mampu.

Dengan cara-cara di atas, pembelajaran siklus II berhasil meningkatkan kemampuan peserta didik dalam melakukan langkahlangkah stock opname seperti yang ditetapkan pada kriteria keberhasilan dalam penelitian tindakan kelas ini yaitu meliputi keberhasilan proses dimana sebanyak 32 anak atau $100 \%$ anak telah memiliki sikap positif berupa meningkatnya motivasi belajar, mendengarkan/ mengamati dengan aktif, berani bertanya, bertanggung jawab, aktif berdiskusi, tertarik mengikuti kegiatan belajar, memiliki semangat dan rasa senang, dan aktif melakukan kegiatan demonstrasi dan keberhasilan produk yang didapatkan dari meningkatnya hasil tes praktik mendemonstrasikan langkah-langkah stock opname dimana sebanyak $100 \%$ atau 32 anak sudah mampu melakukan langkah-langkah stock opname dan dari hasil tes tertulis sebanyak 28 anak atau $87,50 \%$ telah mencapai KKM.

\section{DAFTAR PUSTAKA}

I Gusti Ayu Dariyati. (2015). E- Journal Pascasarjana Universitas Pendidikan Ganesha. Pengaruh Pembelajaran Praktik Berbantuan Media Audio Terhadap Kemampuan Motorik dan Motivasi Belajar Siswa SMP di SLB A Negeri Denpasar Tahun Pelajaran 2014/2015, 5, 1-10.

Muhibbin Syah. (2006). Psikologi Pendidikan dengan Pendekatan Baru, Bandung: PT. Remaja Rosdakarya.

Pupuh Fathur Rochman. (2007). Strategi Belajar Mengajar, Bandung: Refika Aditama.

Rusman. (2010). Model- Model Pembelajaran Mengembangkan Profesionalisme Guru. Jakarta: Reja Grafindo Persada.

Sri Anitah. (2009). Strategi Pembelajaran di $S D$. Jakarta: Universitas Terbuka.

Suyanto dan Asep Djihad. (2013). Bagaimana Menjadi Calon Guru dan Guru Profesional. Yogyakarta: Multi Pressindo.

Zakiah Daradjat dkk. (2008). Metodik khusus Pengajaran Agama Islam Jakarta:PT Bumi Aksara. 